原著

\title{
誘発脳波の臨床的研究
}

\author{
群馬大学医学部第二内科（指尊鴫谷亮一教授） \\ 吉田忠義
}

\section{CLINICAL STUDY ON EVOKED SOMATOSENSORY POTENTIALS}

Tadayoshi Yoshida

The Second Department of Internal Medicine, School of Medicine, Gunma University

(Director: Prof. Ryoichi Shigiya)

\begin{abstract}
概要 近年になつてェレクトロニクスの進歩に伴ない，電子計算機の技術も大きな進歩がもたらされ， これを医学の諸分野に応用するよらな機運になつて来た。著者は体知覚性誘発脳波を臨床神経学の診 断に応用することを目的として，ジギタル型電子計算機を用いて頭皮上から，誘発脳波を導出し，健 康者については，再現性，一般誘発脑波の特改，誘導部位，左右頭皮の比較，左右頭皮の同時誘導， 開眼時と閉眼時との比較，刺激の強さの变化による比較，定間隔刺激とランダム刺激との比較などの

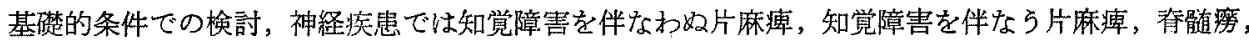

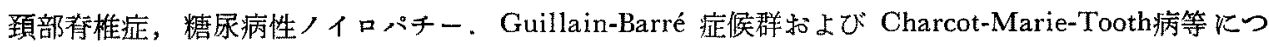
いて恰討し，異常誘発脳波を証明した，以上より誘発脳波の研究は体性知覚の研究に役立ち，かつ臨 床神経学の体知覚能の検查の重要な補助的手段となると結論した。
\end{abstract}

\section{緒論}

ヒトの脳に電気活動が在ることを初めて認めた のはドイッの精神科医Hans Bergerであり，1924 年から研究を始め；その業績を1929年に「人の脳 波について」と題して発表した。一方イヌについ て，光刺激とか未梢神経の電気刺激などによつ て，脳に電気活動が現われるという報告は，それ 以前にもいくつかはあるが, Derbyshine et al., Marshall et al., Bartley et al,, Adrian 5の研究 によつて触覚刺激，または末梢神経の刺激で動物 の大脳皮質表面に様々な電気活動が現われるとい らことが確立された。

ヒトにおける誘発脸波はかなり複雑な波形を小 し, Davis (1939)らによつて初めて, 聴覚, 視覚和 よび体知覚性剌激による誘発脳波が報告された。

本研究恃厚生省新医療技術助成補助金（若林班）に 上る。
Dawson $^{12) 3)}(1947 ， 1954 ）$ にり大脑誘発脳波を 明瞭に取り出すここが，重畳法执よび加算法で可 能となり.大きな進歩がもたらされた。

大脳誘発電位は低振幅の速い電位変化であるた め，背景脸波から区别して，ヒトの頭皮上から導 出することは困難であつたが，近年のェレクト口 ニクスの進歩に伴ない，電子計算技術が取り入れ られて，充分な解像度が得られる電子計算機が製 作され，微弱な電位変化の㛟出と解明に大さな進 步がもたらされた。

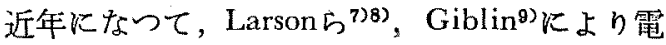
子計算機を使用しての健康者特よび神経资患患者 の体知覚性誘発留位の研究が報告され，種々の知 見が検討解明されて来たが，本邦での开究は未だ

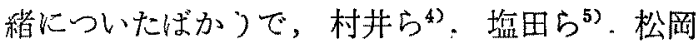
ら ${ }^{6)}$ の学:会報告は散見するが，論文綜説は未だ見 当らないようである。 
著者は体知覚性誘発脳波を臨床神経学の診断特 よび治療に応用することを目的として，ジギタル 型計算機を使用して，頭皮上から誘発脳波を導出 し，健康者については，各種の条件下での基礎実 験を，また病的例では各種の神経疾患の誘発脳波 を記録して，国内拈よび外国の研究結果に近い所 見を得たが，今後に多くの問題点を認め，かつ病 的症例に招いては，従来の臨床的知覚機能検查で は明らかにされない新事実を認め，この方面の研 究が，大いに開発されるべき見解に達したので， 現在までの研究結果をまとめて発表する。

\section{研究対象}

健康者22名扣よび神経疾患患者のうち，脳血 管障害による片麻㿔14名，中枢神経梅毒 5 名， 糖尿病性ノイロパチー10名, 攧部脊椎症 10 名, Guillain-Barre症候群 1 名, 打よびCharcot-MarieTooth病 1 名について研究した。

\section{研究方法}

\section{1）装置の概略}

図 1 は誘発脳波を湘定するさいの装置を簡単な block diagramで示したもので，電気刺激計から 定期的にパルスが出て，末梢(尺骨)神経を刺激 し，頭皮上から誘出される誘発脳波は背景脳波と ともに脳波計で増幅され， digital computerで単 純加算されて，S/N(Signal/Noise) 比を充分大き くしてブラウン管上に映し出される.

2）刺激装置および刺激電極

刺激電極は $\mathrm{Ag}-\mathrm{AgCl}$ ×ッキした直径 $10 \mathrm{~mm}$ 円盤 電極を使用し，时部尺骨神経溝上に置き，不関電 極を前腕に置いた。刺激装置は三栄測器棐電気刺 激装置 E S 103形を用い，60V(一部40V) 1 msecの短矩形波で尺骨神経を経皮的に刺激した。 電気刺激計の作動には後述の電子計算機の附属品 のpulse generator ATAC 103から 3 秒每にtrigger pulseを送つた. 別に random刺激はpulse generator の時間スイッチを適当に変えて，作動パルスを電 気刺激計に送つた。

3）脳波導出装置および誘導部位

導出䉓極は脳波用針電極（三栄測器製 003形）

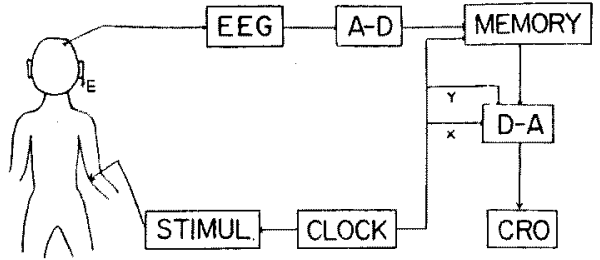

国 1. Block diagram of computer system.

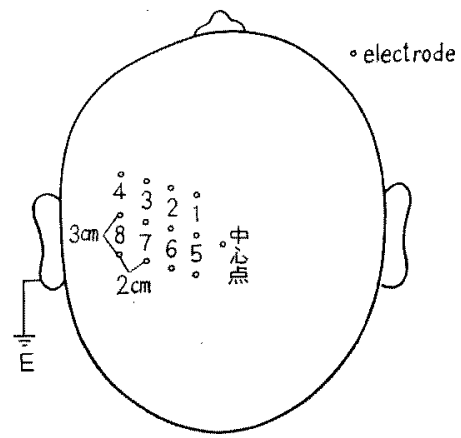

図 2. Schema of lead site, 数字 1 か.58 各数字をはさむ電極間で双極誘導を行なった。

を用い，双極誘導を行なつたつねに誘導電極の 前方のすのをreference leadとし，そのpolarityは ブラウン管上上向きの振れを陰性とした．脳波計 は三栄測器製 E G 130形を用い，かなりgainを上 げて記録した。

誘導部位は（1)刺激と反対側の頭皮上に，まず nasion とinionを結ぶ線上に中点を定め，両耳介 前部とこの中点を通る線上に中点より $2 \mathrm{~cm}$ 間隔で 外側に 4 点を定め，さらにこれらの定点の前方お。 よび後方に $3 \mathrm{~cm}$ 間隔で中心線に平行にそれぞれ 4 点を定めた（図 2 ）。（2）刺激と同側および反詨側 の頭皮上に図 2 のようにして誘導部位 5 にあたる 部位を左右に定め，左右同時誘導を行なつた（病 的例はすべて誘導部位 5 で行なつた)。

4) 電子計算機

電子計算機は日本光電製 A T A C 401 を使用 し，加算時点は刺激時点をもつてなし，加算回数 は 100 回で, analysis timeは 250msecksetし, 1 回の記録に同時 2 channelsを用いた。脳波計の

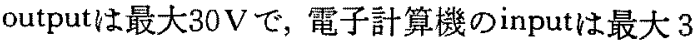
Vなので，途中に陽極および陰極にそれぞれ $1 \mathrm{uF}$ 


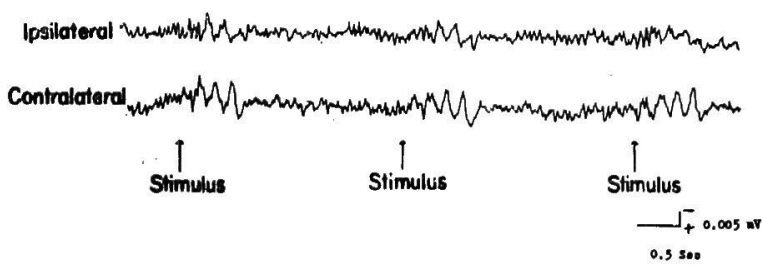

尺骨神経刺激, 誘尊 : 頭頂部

図 3. Evoked electroencephalogram.

$1 \mathrm{M} \Omega$ の C R 結合を置いたＣＲＲ結合の時定数は 1.0 秒, 全回路の総合時定数は 0.23 秒であつた. したがつて下限周波数带域は $0.7 / \mathrm{sec}$ となつた.

\section{5）実験条件}

記録中は被験者に覚醒状態で仰臥位を取らせ， 閉眼させて，できるだけ楽な体位を取らせた。シ ールドルーム内で記録を行ない, 誘導針電㥛は頭 皮上できるだけ直角に骨膜に到達するょうに深く 刺入させた。この状態での電極間の抵抗は扎よそ 25一35K $\Omega$ の間にあつた。

\section{結果}

\section{A）健康人の誘発脳波}

1）誘発脳波について

末梢神経を電気的に刺激すると誘発脳波が現わ れることは前にも述べたが，図 3 は紙送り速度 6 $\mathrm{cm} / \mathrm{sec}$ で, 脳波計のgainを注最大限近くに上げ て取つた双極誘導による誘発脳波である. 刺激に 続いて初めに小さなサイクルの速い波が，続いて 大きなサイクルの遅い波が認められる.その振幅 および持続はかなり個人美があるが，それぞれ拉 よそ $5 \mathrm{uV}$ ，およそ 1 秒である.あるものは $\alpha$ 波に 相当する周期性の波が数回続くのが認められた。 誘発脳波は背景脳波が大きく出る時でも，小さい ことがあり，逆に背景脳波が小さい時でも，誘発 脳波が大きく出ることもあり，誘発脳波と背景脳 波との相関関係は簡単なものでなく，検討の余地 が多い.

2）再現性について

同一人で同じ部位から 2 回別々に加算を行なつ ても, 応答時は同じで, ほぼ同じ波形振幅が得ら れた (図 4 ). 特に初めのサイクルの速い波（pri一

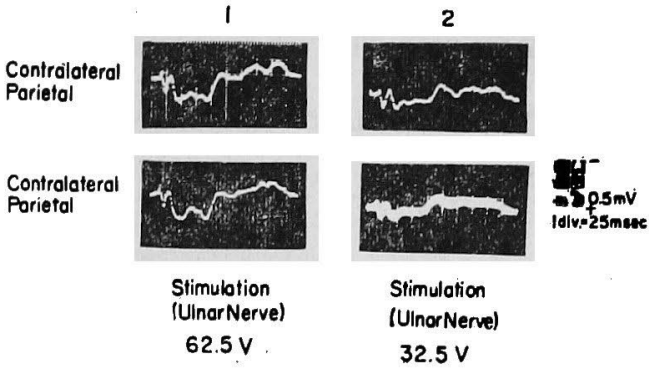

図 4. Reproducibility of evoked cerebral potentials.

mary response, early potentialsともいう) は本質 的には一定である。個人間でも初めのサイクルの 速い波の応答時はほとんど一定であるが，電極の 位置扣よび電極間の距離などにより，波形振幅 は少し異なつている，一方自発脳波を同じtime sequenceで刺激を行なわない状態で加算すると刺 激時に現われるよらな棘波や徐波は現われず，ほ ぼ直線が得られるが，少し徐波傾向を示す波形も 得られる場合もあつた。

3）誘発脳波の極性応答時波形および振幅につ いて

一般に加算誘発脳波は初めに小さい陰性棘波が 現われ，大さな陽性波が続くが，波形については， 早期にサイクルの速い波が現われ，続いてサイク ルの遅い波が認められる。個人間では初めの数相 の波は応答時波形ともに似ているが，以後のサイ クルの遅い波は応答時波形ともにかなりの変動が あつた。

健康者12名について応答時を調べた結果は表 1 のごとくである．著者は誘発脳波の各部に便宜上 $\mathrm{P}_{0}$ (振幅の初めの立ちあがり), $\mathrm{P}_{1}$ (初めの陰性振 幅の頂点), $\mathrm{P}_{2}$ (初めの陽性振幅の頂点), $\mathrm{P}_{3}$ (第 2 の陰性振幅の頂点）……いらように名称を付し た（波形の名称については統一されることが望ま しい).

その応答時は $\mathrm{P}_{0} 10$ - $15 \mathrm{msec}, \mathrm{P}_{1} 15$-20 msec, $\mathrm{P}_{2}$ $20-25 \mathrm{msec}, \mathrm{P}_{3} 30-35 \mathrm{msec}, \mathrm{P}_{4} 35-45 \mathrm{msec}$ と個人 間でほぼ一定の值を取るのにたいし， $\mathrm{P}_{5}$ 以後の応 答時には個人差がかなりあつた(誘導部位 5 )。振 
表 1. Schematic wave pattern of evoked averaged cerebral potentials and response time of each wave in 12 healthy subjects.

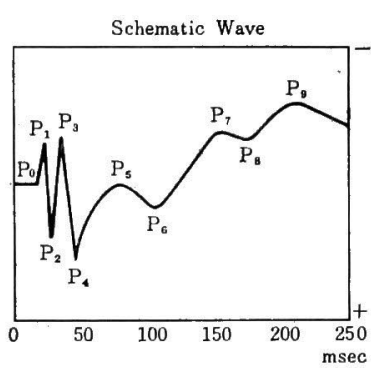

\begin{tabular}{|c|c|c|c|c|c|c|c|c|c|c|c|c|c|}
\hline No & Pt. Nam & Age & Sex & $P_{0}$ & $P_{1}$ & $\mathrm{P}_{2}$ & $P_{s}$ & $P_{4}$ & $P_{5}$ & $P_{6}$ & $\mathrm{P}_{7}$ & $\begin{array}{ll}P_{8} & 1 \\
\end{array}$ & $\mathrm{P}_{0}$ \\
\hline 1 & M. W. & 65 & F & 10 & 20 & 25 & 30 & 35 & 45 & 65 & \begin{tabular}{|l|l|}
80 & 1 \\
\end{tabular} & 1001 & 125 \\
\hline 2 & K. A. & 55 & F & 15 & - & 25 & 30 & 40 & 50 & 65 & \begin{tabular}{ll|l}
75 & 1
\end{tabular} & \begin{tabular}{l|l}
125 & 1
\end{tabular} & 150 \\
\hline 3 & K. T. & 56 & $\mathrm{~F}$ & 15 & 20 & 25 & 35 & 40 & 65 & 901 & 150 & - & - \\
\hline 4 & T. Y. & 57 & M & 15 & 20 & 25 & 30 & 40 & 85 & 110 & 125 & -1 & - \\
\hline 5 & A. 0. & 63 & $\mathrm{~F}$ & 10 & 15 & 25 & 30 & 40 & 75 & \begin{tabular}{|l|l|}
110 & 1
\end{tabular} & \begin{tabular}{l|l}
125 & 2
\end{tabular} & \begin{tabular}{l|l}
200 & 2
\end{tabular} & 225 \\
\hline 6 & M. K. & 46 & M & 15 & 20 & 25 & 30 & 35 & 45 & 55 & \begin{tabular}{ll|l}
90 & 1 \\
\end{tabular} & 1101 & 125 \\
\hline 7 & S. E. & 61 & M & 15 & 20 & 25 & 30 & 40 & 45 & 50 & \begin{tabular}{l|l}
70 & 1 \\
\end{tabular} & $125 \mid 1$ & 175 \\
\hline 8 & I. K. & 51 & M & 15 & 20 & 25 & 30 & 40 & 45 & 65 & \begin{tabular}{l|l}
90 & 1
\end{tabular} & \begin{tabular}{l|l}
115 & 2
\end{tabular} & 210 \\
\hline 9 & H. Y. & 53 & M & .15 & 20 & 25 & 30 & 35 & 50 & 751 & \begin{tabular}{l|l|l}
110 & 2
\end{tabular} & $215-$ & - \\
\hline 10 & K. 0. & 23 & M & 15 & 20 & 25 & 30 & 45 & 70 & \begin{tabular}{l|l}
90 & 1 \\
\end{tabular} & \begin{tabular}{l|l}
110 & 1
\end{tabular} & 1302 & 200 \\
\hline 11 & S. N. & 42 & M & 10 & 15 & 20 & 30 & 40 & 45 & 55 & \begin{tabular}{l|l}
80 & 1
\end{tabular} & \begin{tabular}{l|l|l}
110 & 1
\end{tabular} & 185 \\
\hline 12 & s. 0. & 62 & M & 10. & 15 & 25 & 30 & 40 & 55 & \begin{tabular}{l|l}
80 & 1
\end{tabular} & $150 \mid 1$ & \begin{tabular}{l|l}
175 & 2
\end{tabular} & 225 \\
\hline
\end{tabular}

表 2. Measurement of amplitude $\left(\mathrm{P}_{1} \mathrm{P}_{2}\right)$ in leading site 5 in 10 healthy subjects.

\begin{tabular}{c|c}
\hline 対象 & 振幅( $(\mathrm{mV})$ \\
\hline S. I. & 0.54 \\
\hline K. H. & 0.38 \\
\hline S. T. & 0.35 \\
\hline H. H. & 0.31 \\
\hline H. K. & 0.35 \\
\hline M. Y. & 0.73 \\
\hline S. A. & 0.27 \\
\hline T. I. & 0.42 \\
\hline H. H. & 0.38 \\
\hline H. I. & 0.58 \\
\hline Aver. & 0.43 \\
\hline SD. & 0.135
\end{tabular}

幅 $\mathrm{P}_{1} \mathrm{P}_{2}$ のpeak to peakを実測した結果（健康者10 名）は，表 2 のごとくであり，振幅は $0.27 \mathrm{mVか}$ $50.73 \mathrm{mV}$ と広範囲にわたり，その平均値は 0.43 $\mathrm{mVで}$ 個人間に 相当の開きがあつた（誘導部位 5 ).

4）左右頭皮からの誘導について

健康者12名について，反対側尺骨神経刺激によ る左右頭皮からの誘導結果を検討すると，応答時 は左右ほぼ一定であつた(図 5 )。振幅 $\mathrm{P}_{1} \mathrm{P}_{2}$ は左側 の方が右側より大きいものが 8 名, 右側が左側よ り大きいものが 3 名, 泀涪同じものが 1 名であつ た. 左右振幅の差の一番大きなものは, 大きい方 の扎よそ半分 $47 \%$ もあつたが，多くは20\%から30 \%の間にあつた。

5）左右頭皮の同時誘導について（誘導部位 5 )

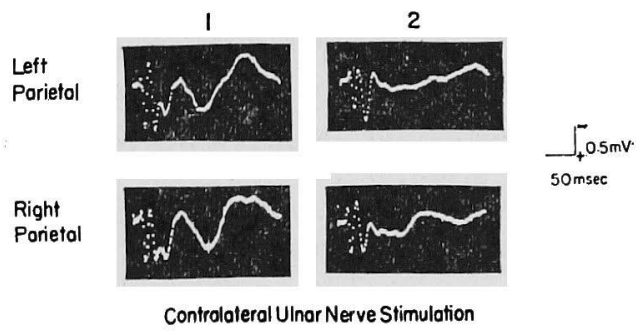

図 5. Comparison between left lead and right lead.
刺激と反対側および同側の頭皮上からの誘導を 検討すると，波形执よび応答時は左右ほぼ同じで あるが，振幅はつねに刺激と反対側の方が刺激と 同側の振幅より大きく（図 6)，刺激と反対側の振 幅 $\mathrm{P}_{1} \mathrm{P}_{2}$ の37.5\%から75\%の大きさであつた（健康 者12名).

6）誘導部位について

誘発脳波が頭皮上のどこで一番著明に現われる かを検討するために，図 2 に示したような誘導部 位を定めた。図 7 は誘発脳波の実記録例である

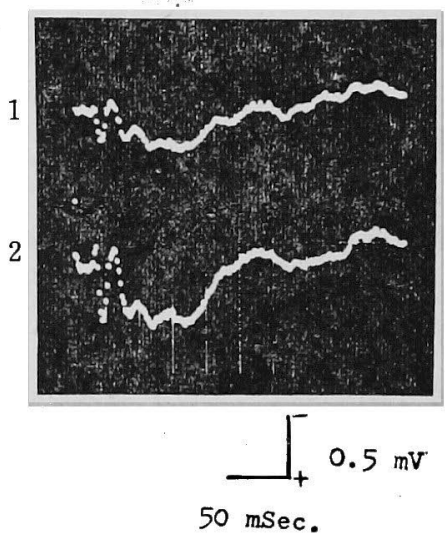

1: ipsilateral to stimulation 2: contralateral to stimulation

図6. Simultaneous recording of evoked potentials. 

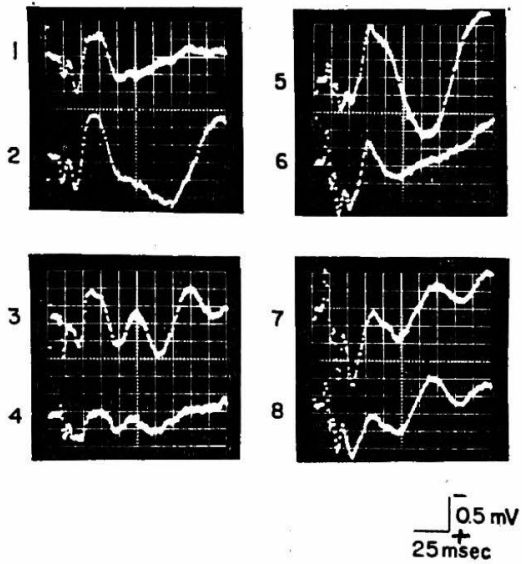

図 7. Example of actual lead by lead site of Fig. 2.

が， $\mathrm{P}_{0}$ から $\mathrm{P}_{4}$ までの応答時および波形については 一定の傾向があるが, 以後の $\mathrm{P}_{5} \mathrm{P}_{6} \cdots \cdots$ の応答時拉 よび波形には一定の傾向が認められない、振幅の 一番よく現われた部位は誘導部位 6 で，一番振幅 の小さかつた部位は誘導部位 1 であつた。

表 3 は健康者10名について, 上記の誘導部位 1 から 8 までの各部位から，振幅 $\mathrm{P}_{1} \mathrm{P}_{2}$ を計測した結 果であるが，その平均値は誘導部位 6 で最も大き $く 0.55 \mathrm{mV}$, 誘導部位 1 で最も小さい值 $0.23 \mathrm{mV}$ を取つて扣り，最高振幅の現われる部位は誘導部 位 6 で 5 名, 誘導部位 3 で 3 名, 誘導部位 4 およ

表 3 . Measurement of amplitude $\left(\mathrm{P}_{1} \mathrm{P}_{2}\right)$ in each lead.

\begin{tabular}{c|c|c|c|c|c|c|c|c}
\hline & 1 & 2 & 3 & 4 & 5 & 6 & 7 & 8 \\
\hline S. I. & 0.35 & 0.50 & 0.35 & 0.35 & 0.54 & $0.62 \bullet$ & 0.42 & 0.27 \\
\hline K. H. & 0.35 & 0.54 & $0.69 \bullet$ & 0.62 & 0.38 & 0.50 & 0.42 & 0.23 \\
\hline S. T. & 0.19 & 0.23 & 0.31 & 0.27 & 0.35 & $0.38 \bullet$ & 0.35 & 0.27 \\
\hline H. H. & 0.12 & 0.19 & $0.50 \bullet$ & 0.38 & 0.31 & 0.38 & 0.31 & 0.38 \\
\hline H. K. & 0.19 & 0.23 & 0.27 & 0.38 & 0.35 & 0.54 & 0.46 & 0.27 \\
\hline M. Y. & 0.35 & 0.54 & 0.65 & 0.62 & 0.73 & $0.85 \bullet$ & 0.69 & 0.65 \\
\hline S. A. & 0.15 & 0.35 & $0.46 \bullet$ & 0.38 & 0.27 & 0.31 & 0.35 & 0.23 \\
\hline T. I. & 0.27 & 0.35 & 0.58 & 0.46 & 0.42 & 0.81 & $1.04 \bullet$ & 0.65 \\
\hline H. H. & 0.15 & 0.35 & 0.38 & $0.46 \bullet$ & 0.38 & 0.38 & 0.31 & 0.23 \\
\hline H. I. & 0.19 & 0.31 & 0.42 & 0.42 & 0.58 & $0.77 \bullet$ & 0.73 & 0.46 \\
\hline Aver. & 0.23 & 0.36 & 0.46 & 0.43 & 0.43 & 0.55 & 0.51 & 0.37 \\
\hline SD. & 0.086 & 0.122 & 0.135 & 0.106 & 0.135 & 0.189 & 0.227 & 0.159 \\
\hline
\end{tabular}

- Maximal amplitude in each lead

単位： $\mathrm{mV}$
び 7 でそそれぞれ 1 名であつた。誘導部位 6 での 振幅を個人間で比較すると，その平均値は 0.55 $\mathrm{mV}$ であり, 最高振幅は0.85mV, 最低振幅は0.31 $\mathrm{mV}$ であつた。その振幅の最低と最高との間には 2 倍以上の差があつた。

7) 閉眼時と開眼時との誘発脳波

図 8 は誘発脳波の記録例を示したもので，閉眼 時および開眼時ともに応答時および波形は同じよ うである。

表 4 は健康者10名について閉眼時および開眼時 の振幅 $\mathrm{P}_{1} \mathrm{P}_{2}$ を計測した結果であるが，各個人につ いて調べると 6 名に閉眼時の振幅の方が開眼時の 振幅より大きく，ほぼ同じ大きさの振幅を示する のが 3 名で, 開眼時の振幅の方が閉眼時の振幅よ り大きいものは 1 名であつた。これを平均でみる

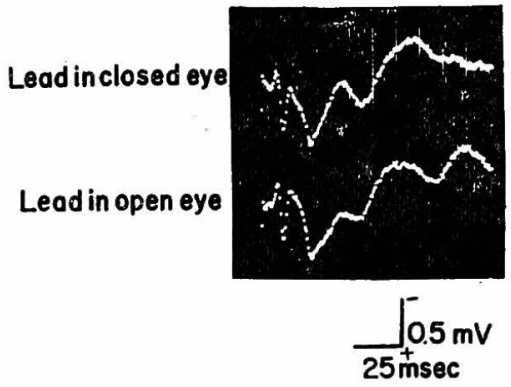

图 8. Averaged evoked cerebral potentials in closed eye and open eye.

表 4. Comparison of amplitude $\left(\mathbf{P}_{1} \mathbf{P}_{2}\right)$ in closed eye and open eye.

\begin{tabular}{|c|c|c|}
\hline & Closed eye & Open eye \\
\hline S. Y. & 0.50 & 0.50 \\
\hline T. T. & 0.92 & $0.96 \%$ \\
\hline I. $\mathrm{K}$. & $0.58 \%$ & 0.50 \\
\hline H. K. & 0.65 & 0.65 \\
\hline T. 0. & $1.15 \nVdash$ & 1.12 \\
\hline S. U. & $\theta .31 \%$ & 0.23 \\
\hline S, A. & $0.35 *$ & 0.31 \\
\hline H. M. & $0.65 *$ & 0.58 \\
\hline H. Y. & $0.38 *$ & 0.35 \\
\hline A. M. & 0.77 & 0.77 \\
\hline Aver. & $0.63 \%$ & 0.60 \\
\hline SD & 0.253 & 0.272 \\
\hline
\end{tabular}

* Larger amplitude in each lead 単位 : $\mathrm{mV}$ 
と, 閉眼時の平均値は $0.63 \mathrm{mV}$ で, 開眼時の平均 値は0.60mVなので，その差はほとんどないとい らべき程度である。

8）刺激の強さを変えた時の誘発脳波

刺激の強さを变えたときの誘発脳波の变化を調 べるために，40Vおよび60Vの 2 種類の刺激電圧 を調べた．図９以誘発脳波の実記録例であるが， この例では応答持および波形はほとんど同じであ るが，振幅は $60 \mathrm{~V}$ 刺激の方が $40 \mathrm{~V}$ 刺激よりや〉大 きくなつている，表 5 は健康者10名について振幅 $\mathrm{P}_{1} \mathrm{P}_{2}$ を測定した結果であるが，その平均值は60 V 刺激で $0.63 \mathrm{mV} ， 40 \mathrm{~V}$ 刺激で0.62mVと汪ぼ同じ である．各個人間では，60V刺激の方が $40 \mathrm{~V}$ 刺激

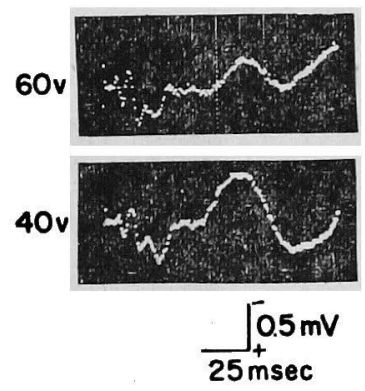

図 9. Averaged evoked cerebral potentials in different stimuli ( $60 \mathrm{~V}$ and $40 \mathrm{~V}$ ) in the same subject.

表 5. Comparison of amplitude $\left(\mathrm{P}_{1} \mathrm{P}_{2}\right)$ in different stimuli ( $60 \mathrm{~V}$ and $40 \mathrm{~V}$ ) in the same subject.

\begin{tabular}{c|c|c}
\hline & $60 \mathrm{v}$ & $40 \mathrm{v}$ \\
\hline S. Y. & 0.50 & 0.50 \\
\hline I. K. & 0.580 & 0.50 \\
\hline T. T. & 0.92 & 1.12 \\
\hline H. K. & 0.650 & 0.27 \\
\hline T. 0. & 1.15 & 1.27 \\
\hline S. U. & 0.31 & 0.23 \\
\hline S. A. & 0.35 & 0.31 \\
\hline H. M. & 0.65 & 0.730 \\
\hline H. Y. & 0.38 & 0.420 \\
\hline A. M. & 0.77 & 0.810 \\
\hline Aver. & 0.63 & 0.62 \\
\hline SD & 0.253 & 0.306 \\
\hline
\end{tabular}

単位: $\mathrm{mV}$

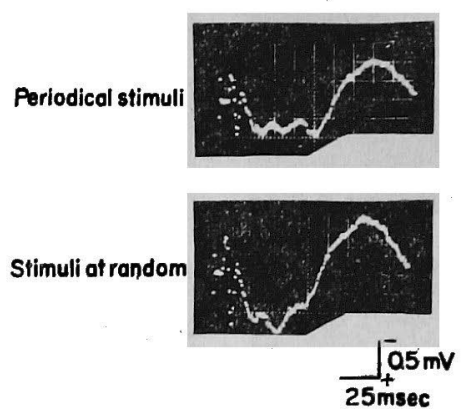

図10. Averaged evoked cerebral potentials in periodical stimuli and stimuli at random.

の振幅より大きいものが 4 名, $40 \mathrm{~V}$ 刺激の方が 60 $\mathrm{V}$ 刺激の振幅より大きいものが 5 名で, 両刺激で ほとんど振幅が同じものが 1 名であり, 両刺激電 圧では振幅はあまり変わらなかつた，応答時およ び波形は両刺激で変わらなかつた。

9）定間隔刺激（ 3 秒間隔）とランダム刺激に よる誘発脳波

3 秒ごとの定間隔刺激と 0.5 秒から 10 秒間隔の ランダム刺激による誘発脳波について検討した。 図10は実際の誘発脳波を示したもので，応答時お よび波形はほとんど同じであるが，ランダム刺激 時の振幅 $\mathrm{P}_{1} \mathrm{P}_{2}$ の方が定間隔刺激時の 振幅 $\mathrm{P}_{1} \mathrm{P}_{2}$ より 大きい. 表 6 は健康者10名について振幅 $\mathrm{P}_{1} \mathrm{P}_{2}$ を測

表 6. Comparison of amplitude $\left(\mathbf{P}_{1} \mathbf{P}_{2}\right)$ in periodical stimuli and random stimuli.

\begin{tabular}{c|c|c}
\hline & Periodical St. & St. at random \\
\hline S. Y. & 0.50 & 0.65 \\
\hline I. K. & 0.58 & 0.73 \\
\hline T. T. & 0.92 & 1.00 \\
\hline H. K. & 0.65 & 0.50 \\
\hline T. O. & 1.15 & 1.38 \\
\hline S. U. & 0.31 & 0.27 \\
\hline S. A. & 0.35 & 0.42 \\
\hline H. M. & 0.65 & 0.88 \\
\hline H. Y. & 0.38 & 0.38 \\
\hline A. M. & 0.77 & 1.12 \\
\hline Aver. & 0.63 & 0.73 \\
\hline SD & 0.253 & 0.340 \\
\hline Karger amplitude in each lead
\end{tabular}

単位: $\mathrm{mV}$ 


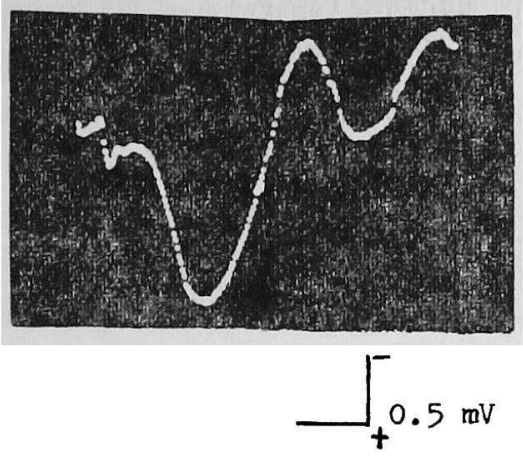

$50 \mathrm{msec}$.

図11. Rhythmic after-discharge (repetitive waves) in healthy subject.

定した結果であるが，ランダム刺激時の振幅の方 が定間隔刺激時の振幅より大きいものが 7 名で, 定間隔刺激時の振幅の 方がrandom刺激時の 振幅 より大きいものが 2 名, 両刺激でほぼ同じ振幅が 1 名認められた。

定間隔刺激時の振幅の 平均値は $0.63 \mathrm{mV}, \mathrm{ran}-$ $\operatorname{dom}$ 刺激時の振幅の平均值は $0.73 \mathrm{mV}$ で, random 刺激時の振幅の方が定間隔刺激時の振幅より大で あつた，波形および応答時は両刺激では任とんど 同じであつた。

10) Rhythmic after-dischargeについて

健康者のらち, primary responseに続いて, 周 期性反復性の波が認められるものがいた（図11）. その周期は $\alpha$ 波に相当する $8-12 \mathrm{cps}$ 波 でこの反 復波は頭皮上の一定部位から認められ，同一人の すべての頭皮上から認められたわけではなかつ た．後述の资髄瘵の 1 例でも認められた。

B ) 神経疾患患者の誘発脳波

著者は誘発脳波を臨床神経学に応用できるかど らかを目的として，臨床的に神経疾患があると 診断された中枢神経および末梢神経疾患患者41名 に，誘発脳波を実測して，その結果について検討 を加えてみた。症例は脳血管障害による片麻疾14 名（知覚障害のないもの 9 名，知覚障害を訴兄 るもの 5 名), 中枢神経梅毒(内, 脊䯙瘵 4 名) 5 名, 糖疗病性ノイロパチー10名, 頝部脊椎症 10 名,

Guillain-Barre症候群 1 名特よびCharcot-MarieTooth病 1 名である.

（1）片麻瘦

a ）知覚障害を訴えない片麻瘏

知覚障害を訴充ない片麻㽻 9 名について誘発脳 波を検討したが，8名は応答時，波形および振幅 で著明な差は認められなかつた(図12)．健康者で 得られた波形，応答時怙よび振幅とくらべても異 常は認められなかつた. 神経学的に構音障害, 眼 振および手に振顫を認めた 1 例で，左右両側に誘 発脳波のprimary responseにあたるものが認めら れなかつた。

b ）知覚障害のある片麻痺

知覚障害，すなわち自覚的に患者がしびれ感を 麻瘨側と同側に訴え, 振動覚および関節覚の低下 している患者 5 名について，その誘発脳波を左右 両側で検討した，波形応答時および振幅を基準に して検討したが，波形の異常および振幅の著明な

Contraloteral

Purietal Lead

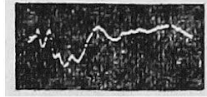

Right Ulnar Nerve St. Left Ulnar Nervo St.

Josmv

図12. Averaged evoked cerebral potentials in a patient suffered from right hemiplegia without sensory disturbance.

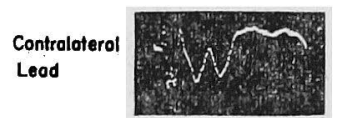

Right Ulnor Nerve St.

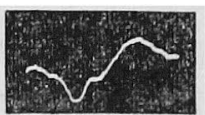

Left Uhar Nerve St.
図13. Averaged evoked cerebral potentials in a patient suffered from left hemiparesthesia and hemiplegia.

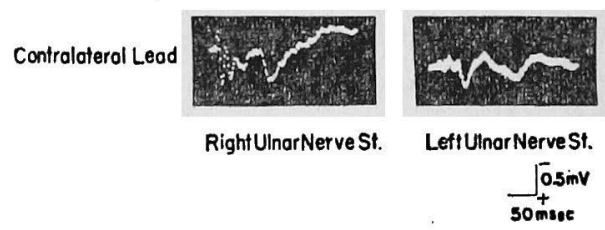

図14. Averaged evoked cerebral potentials in a patient suffered from left hemiparesthesia and hemiplegia. 
Contralateral Parietal

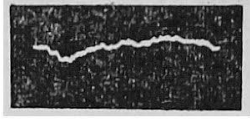

RightUlnarNerveSt.

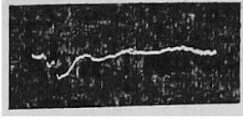

LeftUlnarNerveSt.

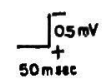

図15. Averaged evoked cerebral potentials in a patient diseased from tabes dorsalis.

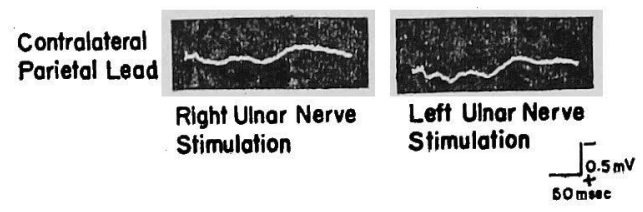

図16. Averaged evoked cerebral potentials in a patient diseased from cervical spondylosis.

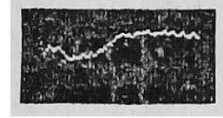

RightUlnarNerve St.

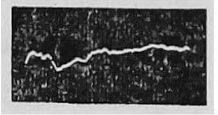

LeffUlnar NerveSt.
図17. Averaged evoked cerebral potentials in a patient diseased from Guillain-Barré syndrome.
Contralaterol
Parietal

Right Ulnar Nerve St.

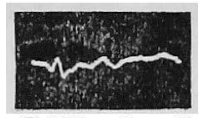

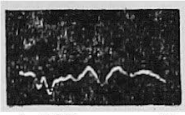

Leff UlnorNerve St.

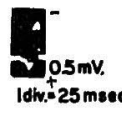

Idh. $25 \mathrm{msec}$

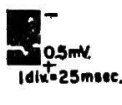

図18. Averaged evoked cerebral potentials in a patient diseased from Charcot-Marie-Tooth disease.

低下が麻痺側からの刺激，すなわら非麻痺側の頭 皮上の誘導により全例に認められた。図13, 図14 は実測した誘発脳波を示したもので, 波形および 振幅の異常が著明であり, その程度はほぼ臨床症 状（しびれの強さ）と相関する。

（2）中枢神経梅毒

中枢神経梅毒患者 5 名（沗髄瘵 4 名, 漣発性先 天梅毒 1 名）について，誘発脳波を検討すると 3 名に異常波形が認められた。図15は実測した 1 例 であるが，健康者の誘発脳波と比べて，primary responseの波形扣よび振幅に異常が認められる. 応答時の遅延は認められなかつたが, 刺激が強す ぎたためかもしれない。
（3）糖尿病性ノイロパチー

糖尿病性/イロパチー10名について誘発脳波を 検討したが，健康者の波形，応答時および振幅な どとくらべて著明な差異は認められなかつたが， 刺激電圧が強すぎたためかもしれない。

（4）頝部脊椎症

顼部春椎症10名について誘発脳波を検討する と，9名は健康者の波形，応答時および振幅など とくらべて，著明な差異は認められなかつた，図 16に示すように 1 例にかなり著明な異常波形を呈 するものがいた。この患者の上肢(両側)の知覚障 害は著明であつた。

（5）その他の神経疾患

頝部以下に対称性に高度の知覚障害を示し, 軽 度の運動機能障害があり, 細胞蛋白解離のあつた Guillain-Barre症候群の 1 例に 図17に示すような 誘発脳波の異常を呈するものがいた．

家族歴があり, 定型的な症状を呈したCharcotMarie-Tooth病の 1 例に応答時の著明な遅延があ り，軽度の波形異常を呈するものがいた（図18）.

考案

1930年代後半には，動物の誘発脳波が直接皮質 内および皮質上に電極を置いて記録され，深く研 究されたが，ヒトの頭皮から誘発脳波を記録する ことは遙かに困難であつた。

ヒトの誘発脳波は頭蓋のために著しく減弱し， それを自発背景脳波と区別して取り出すことは困 難であつたが，Dawson'1238)の発表した重畺法拉 よび加算法で可能となつた.

さらに最近の 10 年間に, 次々と多くの研究が報 告されて，新しい知見が得られて来たが，未だ充 分解明分析されたとはいいがたく，研究者により 使用したcomputer，誘導部位，刺激の強さの違い などが皆違つているので，最終的な結論はない． 相互比較のためには，研究者間に一定した研究方 法, common languageが必要であろう.

著者の研究目的は誘発脳波を臨床神経学に役立 せることであるが，まず実験方法，さらに健康人 および神経疾患患者の誘発脳波について検討考案 
を加えた。

Giblin $^{\text {9), Uttal et al. }}{ }^{20)}$, Larson et al.788), Kelly, Jr. et al. ら ${ }^{11}$ は正中神経を刺激しまた Giblin ${ }^{92}$ は怪骨神経も刺激をして, 反対側の頭皮上から 誘発脳波を記録しているが，著者は尺骨神経刺 激を行なつた。正中神経，尺骨神経，その他どの 神経刺激が一番誘発脳波の記録によいかという結 論はないのが当然である。要は臨床的に誘発脳波 を記録するには，目的にかなつた神経を刺激して 記録すればよい。

Larson $5^{7)}$ は $1 \sim 4 \mathrm{c} / \mathrm{s}$, Goff ${ }^{12)}$ は 4.5〜 6.0 秒間隔で刺激を行なつているが，神経線維の回復

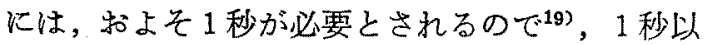
上の刺激間隔があつた方がよい：またAllison ${ }^{18)}$ 刺激後誘発脳波が完全に回復するまでに 4 秒を要 すると報告している．

Giblin'1は刺激による手の反応から，その強度 を3段階に分けて検討を行なつているが，一般に 太い線維の興奮間值は細い線維のそれより低いか ら，適当な刺激では太い線維のみを興奮できる。 神経線維のうち, 深部知覚に関係する神経線維の 太さは，運動神経の $\alpha$ 線維の太さに后注同じであ り，かかる意味において手が肉眼的にかすかに動 く程度刺激することは, 求心性の太い線維(Group 1a，1b）を選択的に刺激することになろう．著者 は60V特よび40V刺激と刺激条件を物理的に一定 にして，刺激を行なつたので，特定の線維群の與 奮を目的としなかつた。

Giblin ${ }^{93}$ は双極誘導で頭頂側頭部に 電極を䁂い $て ，$ Larson $5^{7) 87}$ は頭皮上に多くの 定点を定めて 双極誘導を行なつているが，未だ誘導部位につい ては一定したるのはないようであり，研究者によ り電極間の距離掞よび誘導部位は種々である。し かし多くの研究者は刺激と反対側のRoland溝の 前後，すなわら古典的な知覚領の辺りをすず第一 目標にして研究をしているようである。

頭皮上からの誘導で，はたして記録されたるの が，誘発脳波であるのか，あるいは単なる筋やそ の他からのcontaminationによるartifactにすぎな
いのかといらことが問題であつた．Bickford ${ }^{14)}$ は 頭皮からの誘導は諉発脳波ではなく， myogenic contaminationであるかも知れないと述べたが， Dominoら ${ }^{15}$ は頭皮拈よび硬膜上の同時誘導を行 なつて, Larsonらて はsuccinyl cholineを使つて完 全に筋麻盘を抗こさせて，ともに頭皮上から得ら れるものは誘発脳波であると報告し，さらにLarsonら》は资䯣後索を刺激して，末梢神経刺激と同 じ波形を得たとも報告している。著者は脳波計の gainをかなりあげて，誘発脳波を記録したが，背 景脳波に重なつて刺激に続いて同じようなサイク ルの速い波と，さらにサイクルの途い波を認め， 同一人で誘発脳波を繰り返し取つてもほとんど同 じ波形が認められ，再現性があった。現在頭皮上 から記録されるものはartifactではなく，脳の誘発 電位だと信じられている。

誘発脳波の極性，波形扣よび応答時については かなりの報告があるが，著者の結果も報告された むのとほぼ一致する．Giblin ${ }^{9}$ は誘発脳波の成分 を大きく early potentials とlater wavesとに分けて 検討をし，Allison ${ }^{13)}$ は 5 成分に分けて検討してい る。かれらは初わの各peakをでの応答時は一定で あるが，のちの各Peakむでの応答時は一定ではな かつたと報告している。誘発脳波の波形枕よび 振幅はいくつかの因子に影響されるが，誘導電極 の位置牤よび電極間の距離が最も大きな因子とし て, 重要なるのであり，Goffら ${ }^{12)} は$ 振幅は実験操 作によりかなり差が出ると報告している。

一体どの神経線維群が誘発脳波の発現に関与す るのかが問題であつた. Halliday et al.18), Larson et al.7) は解離性知覚障害患者の 誘発脳波を検討 し，後索およびそれに関連する線維群がこの発現 に関与していると報告し, Uttal et al. ${ }^{10}$ 唀発脳 波をその応答時から，M波，N波，O波に分け， $\mathrm{M}$ 波は後索，N波は资䯣視床路，O波は網様体路 が関係していると報告している。 Larson et al.7) は誘発脳波の波形は脊髄視床路切断術前後で不変 であつたと報告し，Giblin99は振動覚に関係する 求心性の線維で春䯣後索を上行し, 内側毛帯・ 視床中継核を経て，皮質知覚領に投影されるも 
のが，誘発脳波の発現に関与すると報告した。 Larsonら》は末梢神経刺激で視床VPL核 (nucleus ventralis posterior lateralis) で誘発電位を証明し た．著者も関節覚振動覚の低下を伴なつた脳血管 障害性片麻痺の誘発脳波の検討により，深部知覚 に関係する神経線維が，この発現に関係している と推定している。

Goff et al. ${ }^{12}$ 怯小さい陰性波がprimary responseの陽性波に先行するが，これを視床皮質投射路 線維のシナプス前電位であるとし，陽性波はシナ プス後電位であると述べている。

誘発脑波の最大振幅の現尗れる部位は，著者の 結果によれば，刺激と反射側で中心線の中点より $4 \mathrm{~cm}$ 外側扣よびこれより $3 \mathrm{~cm}$ 後方の双極誘道によ るところであるが，この部位は多くの報告とほ注 一致する. Jasper et al.17), Hirsch et al.18)は中心 後回にprimary responseの最大振幅が現われると 報告している。

Larson et al.7) は誘発脳波の振幅は左右で同じ でなく，多くの人で左側の振幅の方が右側のそれ より大きく，その差は20〜25\%あつたと述べてい るが，著者の結果もほぼ同一結果を得た。なぜ左 側が大きく現われるかの理由は不明であるが，利 き手と関係があるのかもしれない。

左右同時誘導による誘発脳波の振幅は刺激と反 対側の振幅がつね机をく，刺激と同側の誘発脳 波の発現は非交㕛性線維によるのではなく，単な るvolume conductionによるといわれているが， 今後に問題点を残している ${ }^{8)}$.

Rhythmic after-dischargeの発生機序は，1)皮質 視床循環回路 (Chang)によるか，2)視床中継核の after-discharge (Adrian)によるかの 2 説'男がある が，不規則な刺激や開眼によつて，多くは除かれ るが，しばしば除去困難であるという。

神経疾患の誘発脳波を検討した報告は少なく， Giblin" ${ }^{97}$ は梢神経疾患，春䯣疾患および脳疾患 について唡討を加点ている，Larsonら ${ }^{8}$ は片麻痺 例について検討を加光，関節覚および振動覚障害 のいちじるしいものに，誘発脳波のいちじるしい
異常を認めたと報告している，著者は脳血管障害 性片麻瘏例でLarsonら ${ }^{8)}$ の 報告にほぼ一致する結 果を得たが，知覚障害を認めない片麻痺の1例に 左右両側でいちじるしく異常な誘発脳波を認め た。资䯣疼患者で早期成分の振幅の減少，波形の 異常を認めたが，応答时の著明な遅延はなかつ た。後索障害を主病变とする瓷䯣痔で，異常誘発 脳波が認められることは重要な臨床的意義が る、糖尿病性ノイロパチーと診断された症例では 晎常波形を認めなかつた。刺激の質と強度に問題 があるのかもしれない，臨床症状の強い頝部凖椎 症の 1 例にも異常波形が認められた。 GuillainBarre症候群おささびCharcot-Marie-Tooth病の各 1 例に誘発脳波の異常を認めたが，末梢かよび中枢 神経の求心路のいずれかに障害が起これば，当然 誘発脳波に異常を来たすであろらと考壳られ，そ の臨床的意義は大きい。

現在誘発脳波の各成分の発生機序については， なおいつそら複雑な成因よりなると考えられてい るが，誘発脳波の検査法は今後臨床的に重要な知 覚機能検查法の一つとなると結論する。

結睔

著者はdigital computerを使用して単純加算を 行なつた誘発細波を健康者および神経疾患患者に ついて, 分析解明して次のような結果を得た。

1）体性知覚を客観的に知る一補助的手段とし てcomputerの使用による誘発脳波の波形，応答時 および振幅の分析解明は有用であり，その神経学 への応用は，未だ緒についたばかりであるが，前 述したような種々の所見から，体性知覚の検查法 として役立つ。

2）加算を繰り返しても，ほぼ同じ誘発脳波が 認められ再現性がある。特にprimary responseは 再現性がある。

3）健康者では泀とんど同じ応答時 $\left(\mathrm{P}_{0} 10-15\right.$ msec, $P_{1} 15-20 \mathrm{msec}, \mathrm{P}_{2} 20-25 \mathrm{msec}, \mathrm{P}_{3} 30-35$ $\mathrm{msec}, \mathrm{P}_{4} 35-45 \mathrm{msec}$ ) を示し, 波形 6 primary responseではほぼ一定の傾向を示す，応答時和上 び波形ともに刺激後 $45 \mathrm{msec}$ 以後はかなり種々の 
值を取る，振幅はかなり個人善がある。

4）刺激と反対側の誘発脳波を左右でくらべる 々, 左頭皮上からの誘発脳波（振幅）が右のそれ より大きかつた。

5）刺激と反対側扰よび同側の左右同時の誘発 脳波は，刺激と反対側で，その振幅は大きかつた が，応答時および波形は変らなかつた。

6）最大振幅の現われる部位は刺激と反対側で 中心線の中点牧よび耳介前部を結ぶ線上，中点よ ク $4 \mathrm{~cm}$ 外側の定点と, 中心線に平行に後方 $3 \mathrm{~cm}$ 定点とによる双極誘導で最大であつた。これは Roland瑇に 沿つたいわゆる古典的な知覚領に相 当する部位である。

7）閉眼時就よ゙開眼時の誘発脳波を比較する と，閉眼時で，その振幅はやや大きかつたが，そ の差はないといらべき程度ですつた，応答時まよ び波形は変らなからた。

8）40V特よび60V刺激です，誘発脳波の波 形，応答時および振幅ははとえど変らなかつた。

9）定間隔刺激より random刺激による誘発脳 波の方が，振幅は少し大きく出る傾向にあつた． 波形顿よび応答時は変らなかつた。

10） $\alpha$ 周期のrhythmic after-dischargesiprimary responsek続いて，健康者沶よび神経疾患患者に 認められた。

11）振動覚，関節覚の低下を伴な5脑血管障害 性片麻㽻例で，患側刺激によりいらじるしい諉発 脳波の波形拉よび振幅の異常を認めた。

12）瓷髄痔患者でも異常誘発脳波が認められ た。糖㽷病性ノイロパチーまよび頝部沗椎症では 異常波形を圼するものは少なかつた。

13) Guillain-Barre症候群执よびCharcot-MarieTooth病でる異常誘発脳波が認められた。

以上より誘発脳波検查法は臨床神経学の知覚機 能検查法として充分役立つものと結論する。

\section{参考文献}

1) Dawson, G.D.: Cerebral responses to electrical stimulation of peripheral nerve in man. J. Neurol. Neurosurg. Psychiat., 10 : 134, 1947. -2) Dawson, G.D.: Cerebral responses to nerve stimulation in man. Brit. med. Bull., $6: 326,1950 .-3$ ) Dawson, G. D.: A summation technique for detection of small evoked potentials. Electroenceph. clin. Neurophysiol., $6: 65,1954 .-4)$ 村茾由之ら：第 19 回日本筋電图学会総会報告，米 子，1966，一5) 塩田勝也ら：第16回日本脱波学会 総会報告, 名古屋, 1967，一6）松岡成明5：第16 回日本睬波学会総会報告，名古屋，1967，一7） Larson, S.J.: Sances, A. Jr., and Christenson, P.C.: Evoked somatosensory potentials in man. Arch. Neurol., $15: 88,1966$. -8) Larson, S.J., Sances, A.Jr., and Baker, J.b.: Evoked cortical potentials in patients with stroke. Circulation, 33, suppl., 2 : 15, 1966. -9) Giblin, D.R.: Somatosensory evoked potentials in healthy subjects and in patients with lesions of the nervous system. Ann. New York Acad. Sci., 112:93, 1964. - 10) Uttal, W.R., and Cook, L.: Systematics of the evoked somatosensory cortical potentials: A psychophysiological-electrophysiological comparison. Ann. New York Acad. Sci., 112 : 60, 1964. 11) Kelly, D.L. Jr., Goldring, S., and Q'Leary, J.L.: Averaged evoked somatosensory responses from exposed cortex of man. Arch. Neurol., 13 : 109, 1965. -12) Goff, W.R., Rosner, B.S., and Allison, T.: Distribution of cerebral somatosensory responses in normal man. Electroenceph. clin. Neurophysiol., $14: 697,1962$. -13) Allison, T.: Recovery function of somatosensory evoked responses in man. Electroenceph. clin. Neurophysiol., $14: 331,1962$. -14) Bickford, R.G., Jacobson, J.L. and Cody, D.T.R.: Nature of average evoked potentials to sound and other stimuli in man. Ann. New York Acad. Sci., 112: 204, 1964. - 15) Domino, E.F., Matsuoka, S. Waltz, J., and Cooper, I.: Simultaneous recordings of scalp and epidural somatosensory evoked reponses in man. Science, 145:1199, 1964. 16) Halliday, A. M., and Wakefield, G. S.: Cerebral evoked potentials in patients with dissocciated sensory loss. Electroenceph. clin. Neurophysiol., 14 : 786, 1962. -17) Jasper, H., Lende, R., and Rasmussen, T.: Evoked potentials from the exposed somatosensory cortex in man. J. nerv, ment. Dis., $130: 526,1960$. -18) Hirsch, J.F., Pertuiset, B., Calvet, J. Buisson-Ferey, J., Fischgold, H., et Scherrer, J.: Etude des réspoonses électrocorticales obtenues chez I'homme par des stimulations somesthesiques et visuelles. Electroenceph. clin. Neurophysiol., 13 : 411, 1961. -19) Ruch, T.C.,Patton, H.D., Woodbury, J.W. and Towe, A.L.: Neurophysiology. 18th edition. W.B. Saunders. Philadelphia and London, 1962. 